\title{
Hydraulic Functions of Peat Soils and Ecosystem Service
}

\author{
Bernd Lennartz* and Haojie Liu \\ Faculty of Agricultural and Environmental Sciences, University of Rostock, Rostock, Germany
}

Keywords: hydraulic functions, ecosystem service, peat soils, available water capacity, preferential flow

Peatlands cover $\sim 3 \%$ of the Earth's land area, but store $~ 30 \%$ of the global soil carbon (C), $10 \%$ of the global soil nitrogen $(\mathrm{N})$, and $10 \%$ of global fresh water (Joosten and Clarke, 2002; Limpens et al., 2008). Drainage of peatlands induce aerobic conditions, which leads to carbon mineralization, peat degradation and concomitant emissions of carbon dioxide $\left(\mathrm{CO}_{2}\right)$ to the atmosphere. It is estimated that $15 \%$ of global peatlands have been drained and are currently being used for agriculture and forestry (Joosten and Clarke, 2002). The drained fraction can be as high as $95 \%$ (e.g., Northern Germany). Drainage leads to subsidence of peat deposits by 0.5-4 m (Wösten et al., 1997; Pronger et al., 2014), and oxidation of peat organic matter from 100 to $20 \mathrm{wt} \%$ (Rezanezhad et al., 2016; Liu and Lennartz, 2019), causing a loss in their water storage and water filter function. Little is known about the function of peat soils with respect to water quantity and quality (Baveye et al., 2016; Rabot et al., 2018; Vogel et al., 2018). We combine key properties such as available water capacity and hydraulic conductivity to classify peat soils with respect to their function in the water cycle. We, also, identify soil physical parameters in order to estimate the filter and buffer potential of

OPEN ACCESS

Edited by:

Philippe C. Baveye,

AgroParisTech Institut des Sciences et Industries du Vivant et de L'environnement, France

Reviewed by:

John Koestel,

Swedish University of Agricultural

Sciences, Sweden

*Correspondence:

Bernd Lennartz

bernd.lennartz@uni-rostock.de

Specialty section:

This article was submitted to

Soil Processes,

a section of the journal

Frontiers in Environmental Science

Received: 28 February 2019

Accepted: 31 May 2019

Published: 21 June 2019

Citation:

Lennartz B and Liu H (2019) Hydraulic

Functions of Peat Soils and

Ecosystem Service.

Front. Environ. Sci. 7:92.

doi: 10.3389/fenvs.2019.00092 peat soils. We established a rating scheme that takes soil degradation into account and classifies the water related ecosystem services provided by peat soils. The classification scheme shall be further developed and may serve as a decision support tool for peatland restoration projects.

\section{SOIL STRUCTURE AND HYDRAULIC FUNCTIONS OF PEAT}

Pristine peat is formed of decayed plants and characterized by a low density and high organic matter content (e.g., $>90$ wt $\%$; Figure 1). The most extraordinary feature of pristine peat is its high porosity, which easily exceeds 90 vol\% with a dominance of macropores $(>50 \mu \mathrm{m}$; Figure 2A). These macropores facilitate water movement and solute transport (Quinton et al., 2009; Rezanezhad et al., 2016). Therefore, greater saturated hydraulic conductivity values $\left(K_{\mathrm{s}}\right)$ are observed in pristine peat than in degraded peat (Figure 2B). Drainage of peatland accelerates carbon mineralization, resulting in a higher bulk density and a lower porosity. Here, we propose bulk density as a proxy for peat degradation (Liu and Lennartz, 2019). The relationship between physical properties and peat degradation has been studied (Boelter, 1969; Schindler et al., 2003). Macropores in low to moderately degraded peat soils (e.g., bulk density $<0.2 \mathrm{~g} \mathrm{~cm}^{-3}$ ) are formed by the undecomposed parent plant material, which functions as a channel/pipe system (Figure 1). With increasing bulk density from 0.2 to $1.0 \mathrm{~g} \mathrm{~cm}^{-3}$, macroporosity remains constant because of the formation of secondary macropores (e.g., root channels; Figure 1; Liu and Lennartz, 2015).

A strong negative linear relationship was observed between total porosity and bulk density $\left(R^{2}=0.82, p<0.001\right.$; Figure 2A). In contrast, a power-law relationship was detected between macroporosity $(>50 \mu \mathrm{m})$ and bulk density (Figure 2A). With an increase in bulk density, from 0.01 to $0.2 \mathrm{~g} \mathrm{~cm}^{-3}, K_{\mathrm{s}}$ decreased dramatically (Figure $2 \mathrm{~B}$ ), because macroporosity is markedly reduced with peatland degradation. A negative linear relationship was observed between $\log _{10} K_{\mathrm{s}}$ and bulk density. With increasing bulk density, from 0.20 to $1.0 \mathrm{~g} \mathrm{~cm}^{-3}, K_{\mathrm{s}}$ almost remains constant with a large variance (Liu and Lennartz, 2019). 


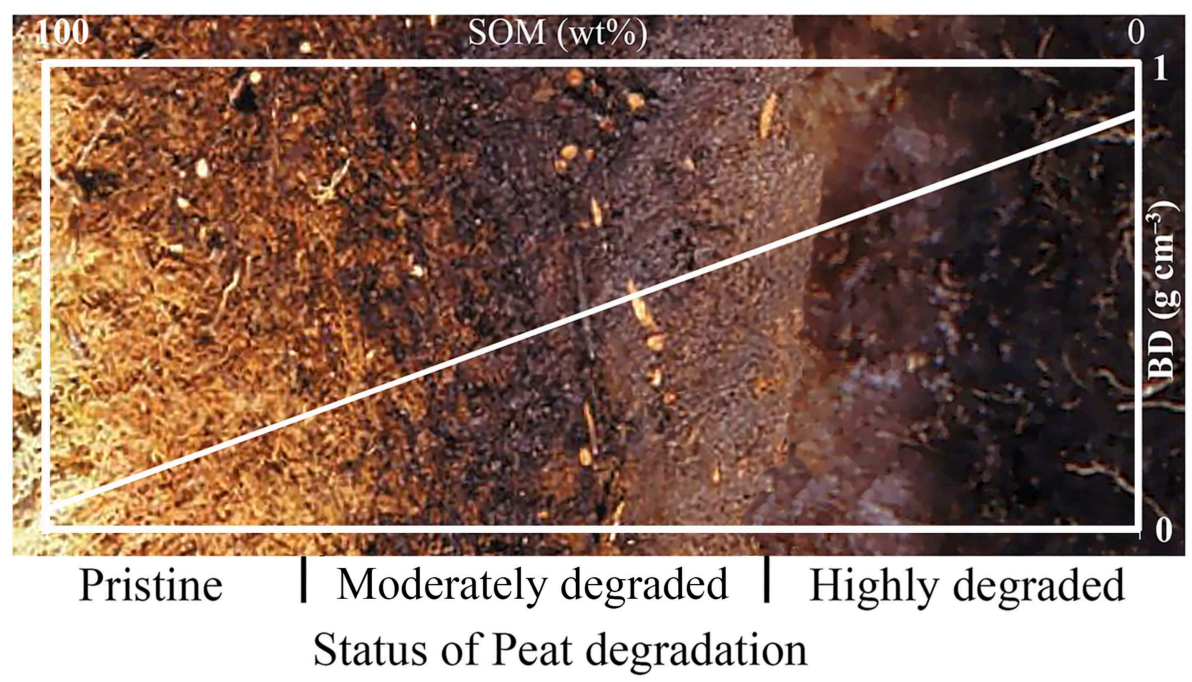

FIGURE 1 | Morphological structure of peat soils at various degradation stages (pristine, moderately degraded, and highly degraded). SOM, soil organic matter; BD, bulk density.

\section{CLASSIFICATION OF PEAT SOIL HYDRAULIC FUNCTION}

We categorized degraded peat soils according to their function in the water cycle. We created five classes of peat soils from pristine (P) to extremely degraded (E). This classification scheme is not based on an expert system (e.g., von Post degradation scheme; Von Post, 1922) but on independently measured bulk density, which assures easy applicability andmore importantly-comparability with different studies.

We suggest a combination of saturated hydraulic conductivity $\left(K_{s}\right)$ with available water capacity as core parameters of soilwater-interactions to characterize a given site in a hydrological sense (Table 1). The available water capacity (AWC) is defined as the volumetric soil water content between matrix potentials at -60 and $-15000 \mathrm{hPa}$ (Schwärzel et al., 2002). It has to be noted that the AWC for peat soils $\left(0.1-0.7 \mathrm{~cm}^{3} \mathrm{~cm}^{-3}\right)$ has a broader range than that for mineral soils $\left(0.1\right.$ to $0.3 \mathrm{~cm}^{3} \mathrm{~cm}^{-3}$; Merdum, 2010). Pristine peat has a low AWC $\left(0.05\right.$ to $0.3 \mathrm{~cm}^{3}$ $\left.\mathrm{cm}^{-3}\right)$. However, water storage, defined as the total water content in length units $\left(\mathrm{W}=\theta^{*} \mathrm{z}\right.$, with $\theta=$ volumetric soil water content and $\mathrm{z}=$ considered soil depth) at the actual ground water table, is nonetheless high because the ground water table in pristine peat is always near the surface. In this situation, macroporosity is included as a part of storage capacity. Soil subsidence and the associated loss of water storage is not reflected in the AWC. We employed the AWC because it is the most commonly and readily available parameter in soil science, even though it does not correctly depict water storage. Also, the definition of water storage capacity depends on various assumptions (e.g., soil volume change by shrinkage and subsidence; Price, 2003), which adds uncertainty to any classification scheme.

Interpretation of the classification scheme must consider current and future management of peatland sites. For instance, if a site is to be rewetted as a restoration measure, minimum requirements of water conductance need to be fulfilled. Difficulty may arise when managing the groundwater table in highly degraded peat soils because of the low hydraulic conductivity.

In cases where water is supplied through storm surges and flooding, as in coastal wetlands, highly degraded peat horizons at the soil surface may hinder water infiltration, causing the formation of shallow lakes. This would mean a systemshift from a (degraded) peatland to a lake ecosystem with severe consequences to bio-geochemical cycling and the biota (Jurasinski et al., 2018). In this context, the derived scheme (Table 1) may help create an appropriate management strategy.

Table 1 indicates that the AWC of pristine and minor degraded peat soils spans a wide range of values (Liu and Lennartz, 2019). High $K_{\mathrm{s}}$ values are only found for pristine and minor degraded peat soils. The high variance in AWC values for pristine and minor degraded peat reflects the presence of a significant fraction of macropores, which easily exceeds $50 \%$ of the total porosity. Small changes in pore structure and/or the method of AWC determination may lead to higher or lower values of AWC. Even highly degraded peat soils might have AWC values exceeding $0.5 \mathrm{~cm}^{3} \mathrm{~cm}^{-3}$, which makes them an important component in overall landscape water storage. If the degradation is severe and the bulk densities are $>0.4 \mathrm{~g} \mathrm{~cm}^{-3}$, AWC decreases, resulting in a loss of ecosystem service.

Soil function is categorized into three classes (Table 1). Green indicates that the peatland provides maximum ecosystem services in terms of water holding capacity and conductance. Such circumstances are found in pristine, minor degraded and moderately degraded peat soils only. Peat soils having $K_{\mathrm{s}}$ values below 1 or even below $0.01 \mathrm{~cm} \mathrm{~h}^{-1}$ are limited in the service they can provide because they function as a hydraulic barrier, which hampers restoration efforts. Gabriel et al. (2018) created an evaluation scheme that classifies the hydraulic properties of 

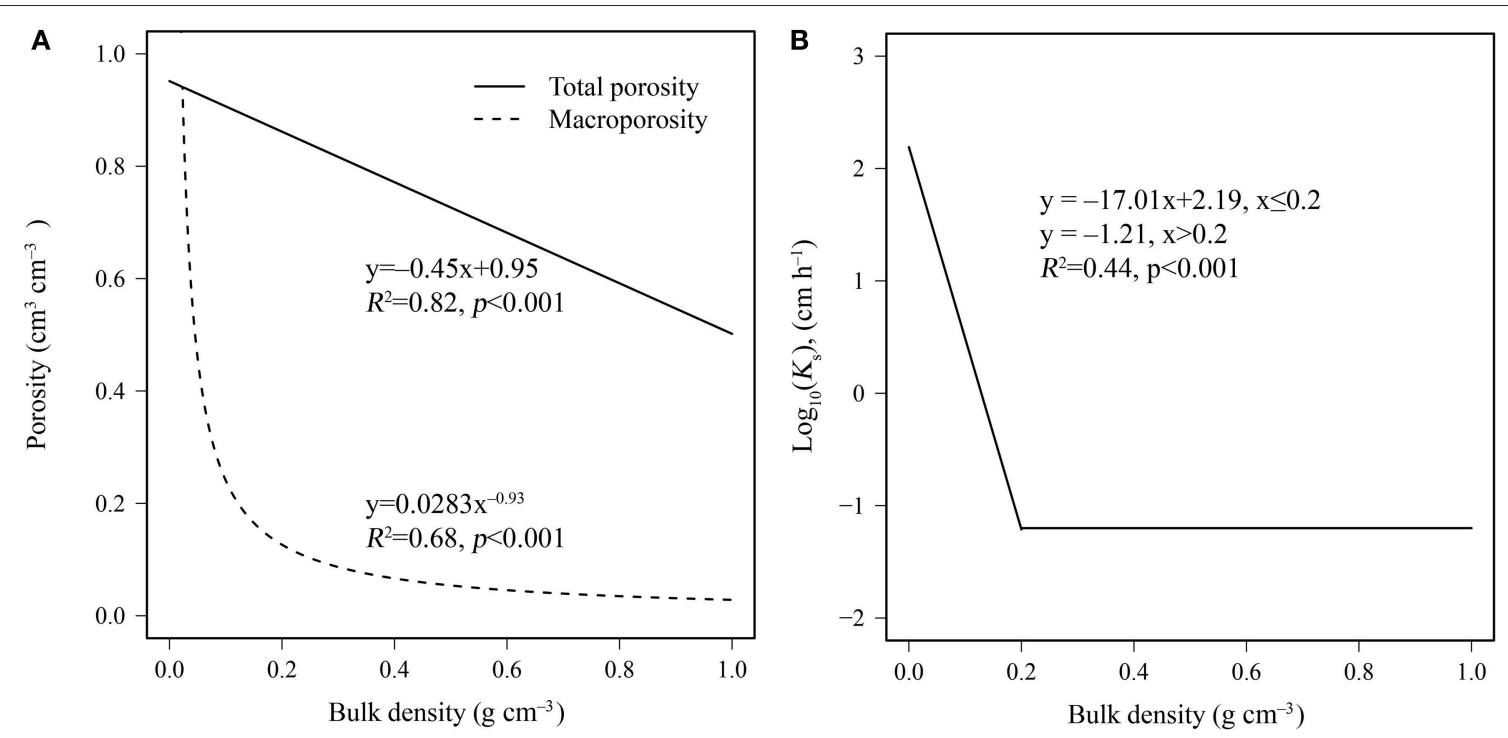

FIGURE 2 | Pore structure (total porosity and macroporosity; A) and saturated hydraulic conductivity $\left(K_{\text {s }}\right.$; B) of peat soils along a bulk density gradient. Data source from Liu and Lennartz (2019).

TABLE 1 | Hydrological classification of degraded peat soils based on saturated hydraulic conductivity $\left(K_{S}\right)$ and available water capacity (AWC, $\mathrm{cm}^{3} \mathrm{~cm}^{-3}$ ).

\begin{tabular}{lllll}
\hline AWC & $\mathbf{0 - 0 . 1}$ & $\mathbf{0 . 1 - 0 . 3}$ & $\mathbf{0 . 3 - 0 . 5}$ & $>\mathbf{0 . 5}$ \\
\hline $\boldsymbol{K}_{\mathbf{s}}$ & $\mathrm{P}$ & $\mathrm{P}$ & $\mathrm{Mi}$ & $\mathrm{Mi}$ \\
$>100 \mathrm{~cm} \mathrm{~h}^{-1}$ & $\mathrm{Mi}$ & $\mathrm{Mi}, \mathrm{M}$ & $\mathrm{M}$ \\
$1-100 \mathrm{~cm} \mathrm{~h}^{-1}$ & & $\mathrm{M}, \mathrm{E}$ & $\mathrm{M}, \mathrm{H}, \mathrm{E}$ & $\mathrm{M}, \mathrm{H}$ \\
$0.01-1 \mathrm{~cm} \mathrm{~h}^{-1}$ & & & $\mathrm{H}$ & $\mathrm{H}$ \\
$<0.01 \mathrm{~cm} \mathrm{~h}^{-1}$ & & & & \\
\hline
\end{tabular}

Value combinations marked in green, yellow, and red provide a high, moderate, and low ecosystem service, respectively. Data source from Liu and Lennartz (2019). P, pristine peat, $B D \leq 0.05 \mathrm{~g} \mathrm{~cm}^{-3} ; \mathrm{Mi}$, minor degradation, $0.05<B D \leq 0.10 \mathrm{~g} \mathrm{~cm}^{-3} ; M$, moderate degradation, $0.10<B D \leq 0.20 \mathrm{~g} \mathrm{~cm}^{-3}$; high degradation, $0.20<B D \leq 0.40 \mathrm{~g} \mathrm{~cm}^{-3}$; E, extreme degradation, $B D>0.4 \mathrm{~g} \mathrm{~cm}^{-3}$.

various peat soils. The classification scheme provided in this study differs from the aforementioned in the way hydraulic properties are combined and the way peat degradation is explicitly addressed.

\section{SOLUTE TRANSPORT AND THE RISK FOR PREFERENTIAL FLOW}

The filter and buffer functions of soil are of prime importance in the estimation of ecosystem services. Peatlands play a crucial role in this because they are frequently located in ecosystem transition zones connecting mineral soils with aquatic ecosystems. For instance, in lowland catchment areas, fen peat is often formed along rivers (riparian fen). Surface and groundwater movement between land and water could pass through a fen. In agricultural settings, where mineral soils are intensively used, and fertilizers and pesticides are massively applied, the filter and buffer function of a riparian fen is the sole element protecting water quality.
However, depending on the history of the peat (e.g., agricultural usage) and current water management, riparian fens may also act as a source, especially for nutrients such as phosphorus (Zak and Gelbrecht, 2007). Coastal wetlands are another example of transition ecosystems that contain peat soils. Coastal peatlands are found, for instance, along the southern Baltic Sea coast where they form unique habitats (Kreuzburg et al., 2018). Rising sea levels and a sinking coast may increase the frequency of flooding of coastal areas. In cases where dunes and dykes are removed for restoration purposes, coastal peatlands might get frequently flooded with seawater. In such situations, the role of peat soil is two-fold. Seawater might carry pollutants such as micro-plastics, which get filtered out in the peatland. Additionally, peat soils are a source of nutrients and complex organic molecules, which might reach coastal waters either with the retreating seawater or with submarine groundwater fluxes originating from the wetland. In either case, sink or source, physical peat properties will determine the extent of exchange and solute transport.

In peat soils, filter and buffer functions will depend on state variables such as hydraulic head and properties, which determine how homogeneously the soil matrix is penetrated by any given compound. It is well-known that solute transport, including preferential transport, in soils is non-equilibrated (Flury et al., 1994; Jarvis, 2007; Vogel et al., 2010). In such cases, a solute bypasses the soil matrix and retention mechanisms are non-operational. Early arrival of high concentrations of hazardous substances in ground and surface waters is a clear indication of non-equilibrium transport (Heathwaite and Dils, 2000; Jørgensen et al., 2002).

Several studies have suggested that a variety of parameters will help quantify non-equilibrium in solute transport (Lennartz et al., 1997; Kamra and Lennartz, 2005; Koestel et al., 2011). Here we suggest the mobility index (MI) as a parameter to 
TABLE 2 | Classification scheme for the "filter and buffer function" of peat soils as based on the macro-porosity and mobility index (MI).

\begin{tabular}{lllll}
\hline \multicolumn{1}{c}{ MI } & $>\mathbf{1 . 2}$ & $\mathbf{0 . 8 - 1 . 2}$ & $\mathbf{0 . 3 - 0 . 8}$ & $<\mathbf{0 . 3}$ \\
Macroporosity & $\mathrm{Mi}$ & & & \\
$>25$ vol\% & $\mathrm{M}$ & $\mathrm{M}$ & $\mathrm{M}$ & \\
$10-25$ vol\% & $\mathrm{M}$ & $\mathrm{M}, \mathrm{H}$ & $\mathrm{M}, \mathrm{H}$ & \\
$5-10$ vol\% & & & $\mathrm{E}$ & $\mathrm{E}$ \\
$<5$ vol\% & & &
\end{tabular}

Value combinations marked in green, yellow, and red are considered to provide a high, moderate, and low buffer function, respectively. The mobility index may serve as an indicator for preferential flow and the risk of fast solute transport (Liu et al., 2017); the lower the value the higher the risk of fast solute transport. MI will depend on the tracer; an ionic tracer, such as bromide, might behave differently in organic rich soils than, for instance, tritium. Data source from Liu et al. (2017). P, pristine peat, $B D \leq 0.05 \mathrm{~g} \mathrm{~cm}^{-3}$; Mi, minor degradation, $0.05<B D \leq 0.10 \mathrm{~g} \mathrm{~cm}^{-3} ; M$, moderate degradation, $0.10<B D$ $\leq 0.20 \mathrm{~g} \mathrm{~cm}^{-3}$; high degradation, $0.20<B D \leq 0.40 \mathrm{~g} \mathrm{~cm}^{-3} ; E$, extreme degradation, $B D>0.4 \mathrm{~g} \mathrm{~cm}^{-3}$.

characterize the extent of preferential flow in soils. The MI is the ratio of measured pore water velocity ( $\left.v_{\text {measure }}\right)$ to fitted pore water velocity $\left(v_{\text {fit }}\right)$ as obtained from a model (Lennartz et al., 1997; Liu et al., 2017). It should be noted that the solute transport database for peat soils is very limited. Only recently a few studies provided solute transport data, which classified peat soils with respect to solute transport (e.g., Liu et al., 2017). Our results have to be considered in the light of data scarcity.

The macro-pores of undegraded peat soil are part of the primary pore space formed by plant residues and form a highly connected space. The macro-porosity of peat soil differs from those of mineral soils because macro-pores in mineral soils belong to the secondary pore space originating from biological activity (worm burrows, plant roots) and formation of soil peds (aggregation). In mineral soil, the macro-pores are often less connected to the rest of the pore space than in pristine peat soil. In landscapes with pristine peat soil and water tables that are close to the soil surface, macro-porosity is also an indicator of connectivity. It can be expected that macro-porous peat soil (macroporosity $>50 \mathrm{vol} \%$ ) is wellconnected to adjacent ecosystems (e.g., mineral soils), because a high saturated hydraulic conductivity ensures (horizontal) water exchange between ecosystem compartments.

We combined macro-porosity with the mobility index, as derived from leaching studies employing conservative

\section{REFERENCES}

Baveye, P. C., Baveye, J., and Gowdy, J. (2016). Soil "ecosystem" services and natural capital: critical appraisal of research on uncertain ground. Front. Environ. Sci. 4:41. doi: 10.3389/fenvs.2016. 00041

Boelter, D. H. (1969). Physical properties of peats as related to degree of decomposition. Soil Sci. Soc. Am. J. 33, 606-609. doi: 10.2136/sssaj1969.03615995003300040033x

Boudreau, J., Caron, J., Elrick, D., Fortin, J., and Gallichand, J. (2009). Solute transport in sub-irrigated peat-based growing media. Can. J. Soil Sci. 89, 301-313. doi: 10.4141/CJSS08023 tracers [Table 2; data source from Liu et al. (2017)]. This combination is used to assess the potential filter and buffer functions provided by a soil (e.g., ecosystem services). For peat soils, conservative tracers such as bromide, are retarded resulting in MI values > 1 (Boudreau et al., 2009; Liu et al., 2017). No solute transport data is available for pristine peat, which could be related to experimental difficulties in handling pristine peat samples with a porosity above 90 vol\%.

In accordance with the scheme for water storage and conductance (Table 1) we developed a system that ranks a peat soil's ability to filter and buffer dissolved compounds. From Table 2, it is evident that extremely degraded peat soils possess a high risk of preferential transport. The risk that these extremely degraded soils are penetrated by compounds from the (permeable) adjacent mineral soils is, however, low because they are not well-connected. A risk for preferential flow might be relevant if a site is to be rewetted. Peat soil may become a source of various compounds. Ground and surface water may become contaminated because mobilized substances are transported along preferential pathways (e.g., DOC, phosphorus etc.). Our classification may help in determining remediation measures; however, the scheme is in the discussion phase and the database needs to be expanded. The suggested approach creates new pathways for creating classification schemes for peat soils.

\section{AUTHOR CONTRIBUTIONS}

HL and BL conceived the study. HL collected data and performed statistical analyses. BL prepared the manuscript.

\section{FUNDING}

This study was funded by the European Social Fund (ESF) and the Ministry of Education, Science and Culture of the federal state of Mecklenburg-Western Pomerania within the framework of the WETSCAPES (ESF/14-BM-A55-0028/16) program. We are also grateful to the support by the Research Training Group Baltic TRANSCOAST program, funded by the DFG (Deutsche Forschungsgemeinschaft) under grant number DFGGRK 2000/1.

Flury, M., Flühler, H., Jury, W. A., and Leuenberger, J. (1994). Susceptibility of soils to preferential flow of water: a field study. Water Resour. Res. 30, 1945-1954. doi: 10.1029/94WR00871

Gabriel, M., Toader, C., Faul, F., Roßkopf, N., Grundling, P., van Huyssteen, C., et al. (2018). Physical and hydrological properties of peat as proxies for degradation of South African peatlands: implications for conservation and restoration. Mires Peat, 21, 1-21. doi: 10.19189/MaP.2018.OMB.336

Heathwaite, A. L., and Dils, R. M. (2000). Characterising phosphorus loss in surface and subsurface hydrological pathways. Sci. Total Environ. 251-252, 523-538. doi: 10.1016/S0048-9697(00)00393-4

Jarvis, N. J. (2007). A review of non-equilibrium water flow and solute transport in soil macropores: principles, controlling factors and consequences for 
water quality. Eur. J. Soil Sci. 58, 523-546. doi: 10.1111/j.1365-2389.2007. 00915.x

Joosten, H., and Clarke, D. (2002). Wise Use of Mires and PeatlandsBackground and Principles Including a Framework for Decision-making. Totnes: International Mire Conservation Group, International Peat Society.

Jørgensen, P. R., Hoffmann, M., Kistrup, J. P., Bryde, C., Bossi, R., and Vilholt, K. G. (2002). Preferential flow and pesticide transport in a clayrich till: field, laboratory, and modeling analysis. Water Resour. Res. 38:1246. doi: 10.1029/2001WR000494

Jurasinski, G., Janssen, M., Voss, M., Böttcher, M. E., Brede, M., Burchard, H., et al. (2018). Understanding the coastal ecocline: assessing sea-land Interactions at non-tidal, low-lying coasts through interdisciplinary research. Front. Mar. Sci. 5:342. doi: 10.3389/fmars.2018.00342

Kamra, S. K., and Lennartz, B. (2005). Quantitative indices to characterize the extent of preferential flow in soils. Environ. Modell. Softw. 20, 903-915. doi: 10.1016/j.envsoft.2004.05.004

Koestel, J. K., Moeys, J., and Jarvis, N. J. (2011). Evaluation of nonparametric shape measures for solute breakthrough curves. Vadose Zone J. 10, 1261-1275. doi: $10.2136 /$ vzj2011.0010

Kreuzburg, M., Ibenthal, M., Janssen, M., Rehder, G., Voss, M., Naumann, M., et al. (2018). Sub-marine continuation of peat deposits from a coastal peatland in the Southern Baltic Sea and its holocene development. Front. Earth Sci. 6:103. doi: 10.3389/feart.2018.00103

Lennartz, B., Kamra, S. K., and Meyer-Windel, S. (1997). Field scale variability of solute transport parameters and related soil properties. Hydrol. Earth Syst. Sci. 1, 801-811. doi: 10.5194/hess-1-801-1997

Limpens, J., Berendse, F., Blodau, C., Canadell, J. G., Freemann, C., Holden, J., et al. (2008). Peatlands and the carbon cycle: from local processes to global implications-a synthesis. Biogeosciences 5, 1475-1491. doi: 10.5194/bg-5-1475-2008

Liu, H., Forsmann, D. M., Kjærgaard, C., Saki, H., and Lennartz, B. (2017). Solute transport properties of fen peat differing in organic matter content. J. Environ. Qual. 46, 1106-1113. doi: 10.2134/jeq2017.01.0031

Liu, H., and Lennartz, B. (2015). Visualization of flow pathways in degraded peat soils using titanium dioxide. Soil Sci. Soc. Am. J. 79, 757-765. doi: $10.2136 /$ sssaj2014.04.0153

Liu, H., and Lennartz, B. (2019). Hydraulic properties of peat soils along a bulk density gradient-A meta study. Hydrol. Process. 33, 101-114. doi: 10.1002/hyp.13314

Merdum, H. (2010). Alternative methods in the development of pedotransfer functions for soil hydraulic characteristics. Eurasian J. Soil Sci. 43, 62-71. doi: 10.1134/S1064229310010084

Price, J. S. (2003). Role and character of seasonal peat soil deformation onthe hydrology of undisturbed and cutover peatlands. Water Resour. Res. 39:1241. doi: 10.1029/2002WR001302

Pronger, J., Schipper, L. A., Hill, R. B., Campbell, D. I., and McLeod, M. (2014). Subsidence rates of drained agricultural peatlands in New Zealand and the relationship with time since drainage. J. Environ. Qual. 43, 1442-1449. doi: 10.2134/jeq2013.12.0505

Quinton, W., Elliot, T., Price, J., Rezanezhad, F., and Heck, R. (2009). Measuring physical and hydraulic properties of peat from X-ray tomography. Geoderma 153, 269-277. doi: 10.1016/j.geoderma.2009. 08.010

Rabot, E., Wiesmeier, M., Schlüter, S., and Vogel, H. J. (2018). Soil structure as an indicator of soil functions: a review. Geoderma 314, 122-137. doi: 10.1016/j.geoderma.2017.11.009

Rezanezhad, F., Price, J. S., Quinton, W. L., Lennartz, B., Milojevic, T., and Van Cappellen, P. (2016). Structure of peat soils and implications for water storage, flow and solute transport: a review update for geochemists. Chem. Geol. 429, 75-84. doi: 10.1016/j.chemgeo.2016 03.010

Schindler, U., Behrendt, A., and Müller, L. (2003). Change of soil hydrological properties of fens as a result of soil development. J. Plant Nutr. Soil Sci. 166, 357-363. doi: 10.1002/jpln.200390055

Schwärzel, K., Renger, M., Sauerbrey, R., and Wessolek, G. (2002). Soil physical characteristics of peat soils. J. Plant Nutr. Soil Sci. 165, 479-486. doi: 10.1002/ 1522-2624(200208)165:4<479::AID-JPLN479>3.0.CO;2-8

Vogel, H. J., Bartke, S., Daedlow, K., Helming, K., Kögel-Knabner, I., Lang, B., et al. (2018). A systemic approach for modeling soil functions. Soil 4, 83-92. doi: 10.5194/soil-4-83-2018

Vogel, H. J., Weller, U., and Ippisch, O. (2010). Non-equilibrium in soil hydraulic modelling. J. Hydrol. 393, 20-28. doi: 10.1016/j.jhydrol.2010. 03.018

Von Post, L. (1922). Sveriges Geologiska Undersöknings torvinventering och några av dess hittils vunna resultat (SGU peat inventory and some preliminary results). Svenska Mosskulturföreningens Tidskrift 36, 1-37.

Wösten, J. H. M., Ismail, A. B., and van Wijk, A. L. M. (1997). Peat subsidence and its practical implications: a case study in Malaysia. Geoderma 78, 25-36. doi: 10.1016/S0016-7061(97)00013-X

Zak, D., and Gelbrecht, J. (2007). The mobilisation of phosphorus, organic carbon and ammonium in the initial stage of fen rewetting (a case study from NE Germany). Biogeochemistry 85, 141-151. doi: 10.1007/s10533-00 7-9122-2

Conflict of Interest Statement: The authors declare that the research was conducted in the absence of any commercial or financial relationships that could be construed as a potential conflict of interest.

Copyright (c) 2019 Lennartz and Liu. This is an open-access article distributed under the terms of the Creative Commons Attribution License (CC BY). The use, distribution or reproduction in other forums is permitted, provided the original author(s) and the copyright owner(s) are credited and that the original publication in this journal is cited, in accordance with accepted academic practice. No use, distribution or reproduction is permitted which does not comply with these terms. 